\title{
EFFECTS OF SOIL AND CLIMATE IN A TABLE GRAPE VINEYARD WITH COVER CROPS. IRRIGATION MANAGEMENT USING SENSORS NETWORKS
}

\section{EFEITOS DO SOLO E CLIMA NUMA VINHA DE UVA DE MESA COM CULTURA DE COBERTURA. GESTÃO DA REGA UTILIZANDO REDES DE SENSORES}

\author{
Roque Torres $^{1 *}$, Giuseppe Ferrara ${ }^{3}$, Fulgencio Soto ${ }^{1}$, Juan A. López ${ }^{1}$, Francisco Sanchez ${ }^{2}$, Andrea Mazzeo ${ }^{3}$, \\ Alejandro Pérez-Pastor ${ }^{1}$, Rafael Domingo ${ }^{1}$ \\ ${ }^{1}$ Division of Electronic Engineering and Systems. Technical University of Cartagena. Campus de la Muralla s/n Cartagena. \\ ${ }^{2}$ Department of Fluid and Thermal Engineering, Technical University of Cartagena. Campus de la Muralla s/n Cartagena. \\ ${ }^{3}$ Department of Soil, Plant and Food Science. University of Bari. Via Amendola 165/A. Bari-Italy.
}

*Corresponding author: Tel.: +34968325474, Fax: +34968325345, e-mail: roque.torres@upct.es

(Received 15.05.2016. Accepted 29.06.2017)

\section{SUMMARY}

The use of mulches in vineyards and orchards is a traditional agricultural practice used with the aim of saving moisture, reducing weed growth and improving organic matter content in the soil. In table grape vineyards trained to overhead system in Puglia region (Southeastern Italy), plastic sheets covering the canopy are often used to either advance ripening or delay harvest. In this environment, the living mulches could contribute to the modification of the microclimate around the canopy below the plastic sheets. This condition has an influence on the climatic demand and on both the vegetative and productive activities, mainly in stages with a high evapotranspiration. However, the presence of living mulches could increase the demand of available water and nutrient resources and this could cause a lower yield. The aim of this study was to acquire a suitable knowledge to manage irrigation and verify the influences of living mulches on the vine by using wireless sensor networks to measure the vapor pressure deficit, soil water potential and content.

\section{RESUMO}

A utilização de coberturas do solo em vinhas e pomares é uma prática agrícola tradicional, utilizada com o objetivo de preservar a humidade do solo, reduzir o crescimento de infestantes e melhorar o teor de matéria orgânica no solo. Em vinhas de uva de mesa, conduzidas em sistema de pérgula na região de Puglia (sudeste da Itália), são frequentemente usadas coberturas de plástico para promover o avanço da maturação ou o atraso da colheita. Neste ambiente a utilização de enrelvamentos pode contribuir para a modificação do microclima do copado. Esta condição pode influenciar a demanda atmosférica, bem como a atividade vegetativa e reprodutiva da videira, principalmente em períodos de elevada evapotranspiração. No entanto, a presença do enrelvamento pode originar um aumento da demanda dos recursos disponíveis, nomeadamente água e nutrientes, o que poderá provocar uma quebra de produção. O objetivo deste estudo foi adquirir conhecimento para a gestão da rega e, simultaneamente, verificar a influência dos enrelvamentos na atividade da videira, usando para o efeito redes de sensores "sem fio" para medir o déficit de pressão de vapor, o potencial e o conteúdo de água no solo.

Key words: water management, vineyard, living mulch, WSN.

Palavras-chave: gestão da água, vinha, culturas de cobertura, WSN.

\section{INTRODUCTION}

In agriculture, weeds control is an important issue because weeds highly compete for the available nutrients and water resources, and according to some researches, they could affect yield up to the $80 \%$ (Cousens \& Mortimer, 1995). Such control is traditionally undertaken by plowing (mechanical control of weeds) and/or using herbicides (chemical control). However, the consumers are asking to use less herbicides and the utilization of these products is being reduced due to environmental reasons, such as, the emergence of herbicide resistant weeds and the 
increase of organic food demand (Carter et al., 1991; Major, 1992).

The growth of weeds could be controlled by using organic and synthetic mulches, such as waste material of the olive oil industry (Ferrara et al., 2015, 2012a). The utilization of specific species as living mulch, in combination with drip irrigation, provides both organic matter and nutrients (Welker and Glenn 1988). Additionally, the presence of the living mulch improves the water retention capacity of the soil, and the erosion is consequently reduced (Haynes, 1980; Merwin et al., 1995; Verdú and Mas, 2007). Hall et al. 1984 measured water runoff volume in a corn field planted on a $14 \%$ slope and grown conventionally, managed with no-till or with a crown vetch living mulch. The water runoff in the conventional corn field was reduced by $90 \%$ and $98 \%$, in the no-tilled and mulched with crown vetch plot, respectively.

In the specific case of table grape grown in Puglia, Southeastern Italy, vines trained to overhead system are often covered with plastic sheets to either advance ripening or delay the harvest, and the presence of a living mulch could modify the microclimatic conditions of the vine with effects on vigour and, consequently, on the water needs (Hartwig and Ammon 2002).

The use of living mulch generates a specific microclimate since transpiration is higher as a consequence of the presence of a crop in the interrow. In addition, soil water conditions could also vary because of the presence of the living mulch. The parameters of such environment could be measured by using a set of specific environmental and soil sensors. These measurements can provide information about the influence of living mulch on several parameters. In particular, different sensors should be deployed in the soil with the purpose of obtaining the appropriate determination of the variables. Such sensors should be installed in different sites of the vineyards so that the whole crop is monitored as accurate as possible.

Agricultural sensors, uzed for monitoring soil, plant and climatic parameters, are usually connected to dataloggers. These devices store the acquired data so that they could be used by the operator where they are required. The main problem of these devices is that they are the key element of a wired network, where several meters of wire should be deployed between the datalogger and the corresponding sensor. It is an important issue that should be taken into account when deploying a set of distributed sensors, and it could be difficult to install such sensors at the required locations due to this limitation. Some manufactures (Spectrum Technologies Inc. Aurora,
IL, USA) have developed autonomous (working with batteries) and low size dataloggers, which could acquire data of up to 4 sensors. These characteristics (in combination with a remote data accessing and the autonomous capability of managing the required energy for working), have promoted the use of both autonomous and wireless flexible communications platforms, which are named Wireless Sensors Networks (WSNs). They have been used by several authors to conduct trials in agricultural crops (Morais et al. 2008, Navarro et al. 2015).

Wireless Sensors Network is a measurement platform used nowadays in agriculture to manage water resources (Navarro et al. 2015), since it has great flexibility for measuring parameters in agricultural field. Soil, plant and climatic parameters can be measured using a wireless sensor network that comprises different nodes with several typical parts: a radio transceiver, an antenna, a microcontroller and a battery with an energy-harvesting system. Each node could work in different places without wires (López et al. 2015).

Data acquired by each node are sent to a receiver node, named coordinator, which receives the information from all sensor nodes that comprise the whole WSN. Such coordinator node is in charge of both managing the information and transmitting it to the servers that store the data. WSNs have gradually evolved towards mobile networks, based on machine to machine communications (M2M), thanks to the wide increase in mobile communications, the reduction in the data rates and the growth experimented in the communication speed of such networks. This means that the data acquired by the sensor node are directly transmitted to the servers hosted in the cloud by using GSM mobile networks. In this case, the economic cost is affordable.

In this work, soil and environmental parameters have been monitored in a table grape vineyard covered with a plastic sheet, and with a living mulch in the inter-row. Specifically, wireless sensor nodes equipped with a mobile network transceiver have been used. The acquired data have been stored in remote servers using cloud computing techniques. This paper analyzes the effects of a living mulch on both soil and microclimate parameters measured by using a wireless sensors platform.

\section{MATERIAL AND METHODS}

The trial was conducted in a table grape vineyard in 2015. Italia grapevines grafted onto $1103 \mathrm{P}$ of similar growth and vigour were selected for the study (application of sensors). The vineyard was located in 
the territory of Adelfia (Bari province), Puglia region, Southeastern Italy. Vines were spaced $2.2 \times 2.8 \mathrm{~m}$, trained to an ypsilon trellis system with four fruiting canes/vine (40-50 buds/vine) and were drip irrigated (3 emitters of $4 \mathrm{~L} \cdot \mathrm{h}^{-1}$ per vine). The vineyard was covered with a plastic sheet in order to advance ripening. Specifically, the trial was conducted in two contiguous plots (see Figures 1 and 2), the first one with a living mulch (Trifolium repens) in the interrow (clover seeded on winter 2014), and the latter with a clean soil which was periodically ploughed (Figure 1 and Figure 2). The trial was conducted from budbreak up to the grape harvest.

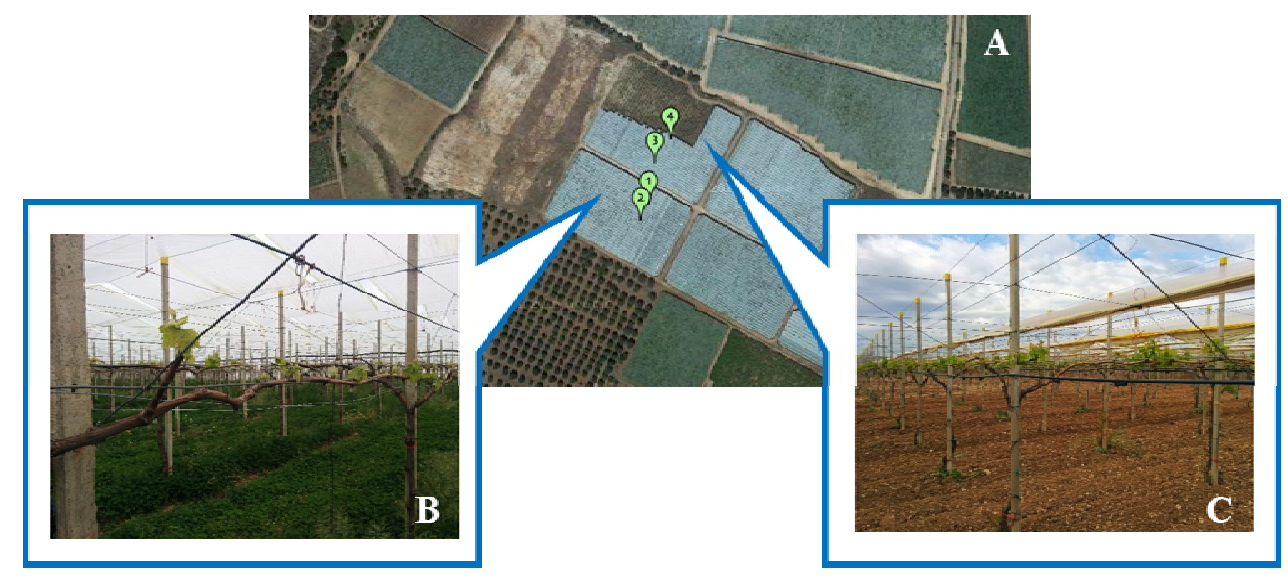

Figure 1. (A) Localization of the nodes in the vineyard. (B) Plot with living mulch. (C) Tilled plot.

(A) Localização dos nós na vinha. (B) Parcela com cobertura vegetal viva. (C) Parcela mobilizada.

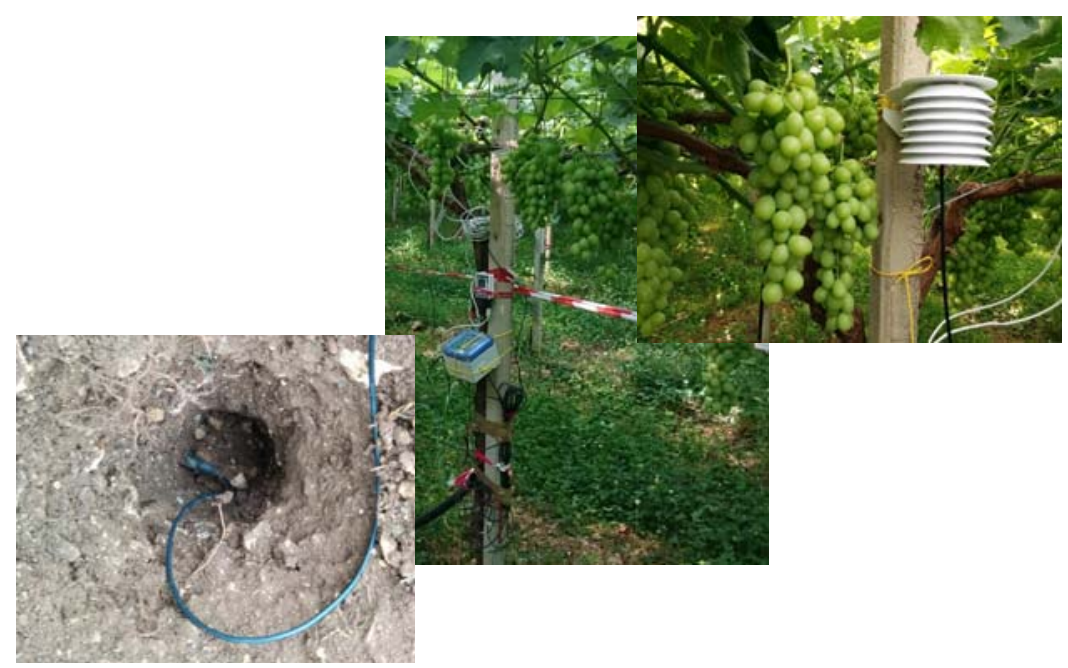

Figure 2. (A) Installation of soil moisture sensor. (B) Wireless sensor node. (C) Environmental sensor.

(A) Instalação do sensor de humidade do solo. (B) Nó do sensor sem fio. (C) Sensor ambiental.

The same number and type of sensors were installed in both plots. Such sensors and the associated measured variables are listed in Table 1.

The mentioned parameters were measured by using one GPRS communication and control sensor node in each monitoring point. Specifically, precision agriculture systems, based on wireless nodes and cloud computing approaches for both storing and processing the information in the cloud, were used (Widhoc Smart Solutions S.L., MU - Spain). The sensor nodes are autonomous from the energy point of view and maintenance is almost non-existent. They were installed above the vine canopy with the purpose of ensuring that the recharging solar system could properly work. 


\section{TABLE I}

Description of the used sensors and the acquired parameters in both crops.

Descrição dos sensores usados e parâmetros adquiridos em ambas as culturas.

\begin{tabular}{|c|c|c|c|c|c|c|c|}
\hline Sensor & Measured data & Output & Range & Resolution & $\begin{array}{c}\text { Supply } \\
\text { voltage range } \\
\end{array}$ & Power & URL \\
\hline VP3 & $\begin{array}{l}\text { vapor pressure, } \\
\text { temperature and } \\
\text { relative humidity }\end{array}$ & SDI-12 & $\begin{array}{c}0 \text { to } 47 \mathrm{kPa} \\
-40^{\circ} \text { to }+80^{\circ} \mathrm{C} \\
0 \text { to } 100 \% \mathrm{RH}\end{array}$ & $\begin{array}{cc}0.01 & \mathrm{kPa} \\
1 & \stackrel{\circ}{\mathrm{C}} \\
0.1 \% & \mathrm{RH}\end{array}$ & 3.6-15 VDC & $4 \mathrm{~mA}$ & http://www.decagon.com/ \\
\hline HP II & $\begin{array}{c}\text { moisture, } \\
\text { conductivity and } \\
\text { temperature }\end{array}$ & SDI-12 & $\begin{array}{c}0 \text { to } 100 \% \mathrm{VWC} \\
0.01 \text { to } 1.5 \mathrm{~S} / \mathrm{m} \\
-10^{\circ} \text { to }+65^{\circ} \mathrm{C}\end{array}$ & $\begin{array}{c} \pm 0.3 \% \text { VWC } \\
\pm 0.0014 \mathrm{~S} / \mathrm{m} \\
\pm 0.6{ }^{\circ} \mathrm{C}\end{array}$ & 9-20 VDC & $30 \mathrm{~mA}$ & http://www.stevenswater.com/ \\
\hline MPS-6 & $\begin{array}{l}\text { soil matric } \\
\text { potential and } \\
\text { temperature }\end{array}$ & SDI-12 & $\begin{array}{l}-10 \text { to }-500 \mathrm{kPa} \\
-40^{\circ} \text { to }+50^{\circ} \mathrm{C}\end{array}$ & $\begin{array}{c}0.1 \mathrm{kPa} \\
0.1^{\circ} \mathrm{C}\end{array}$ & 6-15 VDC & $10 \mathrm{~mA}$ & http://www.decagon.com/ \\
\hline SM 100 & soil moisture & $0.5-1.5 \mathrm{~V}$ & 0 to $100 \%$ VWC & $0.1 \% \mathrm{VWC}$ & 3-5 VDC & $10 \mathrm{~mA}$ & http://www.specmeters.com/ \\
\hline
\end{tabular}

Two repetitions were installed per trial and each of them was equipped with the following sensors (see Figure 2):

- Two SM100 sensors for monitoring the volumetric soil water content $(\theta \mathrm{v})$. They were deployed below the drip emitter at either 25 and 50 cm of depth.

- A HP2 multiparametric probe installed at 25 cm of depth.

- A MPS-6 Soil Water Potential sensor deployed at both 25 and $50 \mathrm{~cm}$ of depth.

- A VP3 environmental sensor located in the canopy.

- $\quad$ A Pluviometer connected to the drip emitter with the purpose of measuring the volume of water supplied to the crop.

The irrigation management was carried out keeping the water potential between -20 and $-30 \mathrm{kPa}$ in both plots, using the measurements acquired from the matric water potential sensor (Figure 3). The purpose was to keep non-limiting conditions of the water in the soil. Using drip irrigation and considering our cultivation conditions, the highest root density is located between 5 and $35 \mathrm{~cm}$ deep. The tensiometer was placed at $25 \mathrm{~cm}$ of depth in order to reflect this root activity. Figure 3 shows the evolution of water tension and irrigation episodes. The sensor nodes were equipped with a pluviometer with the aim of knowing when the irrigation was switched on/off. On the other hand, the total amount of irrigation water was measured by using flow meters in each plot.

Data were stored in servers of Widhoc Smart Solutions S.L. (Fuente Alamo, MU - Spain) by using the M2M service provided by the Italian mobile 4G Company WIND. The data analysis was carried out by using the MatLAB software.

Nodo 2. Vineyard Living Mulch

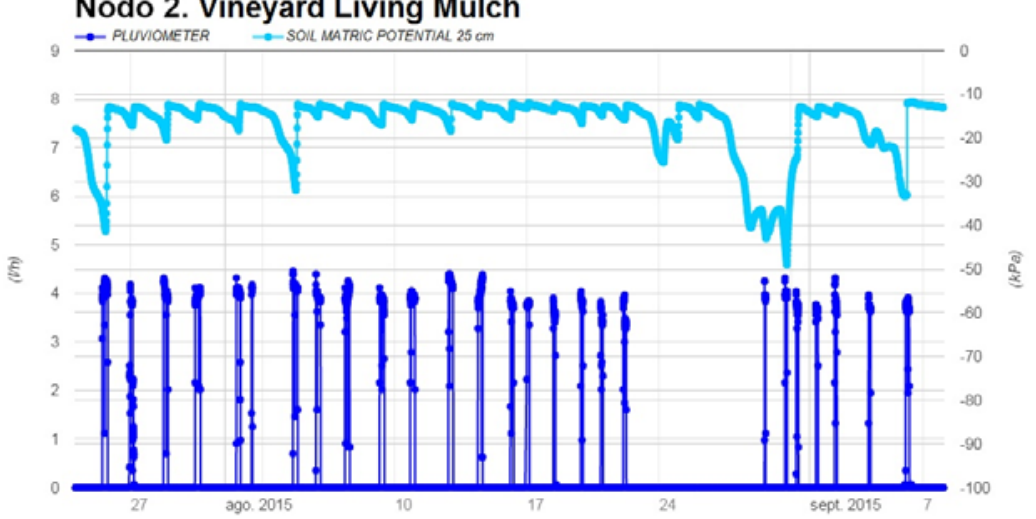

Figure 3. Soil matric potential data and irrigation volume applied. The interface shown is used for irrigation managing with MPS-6 and pluviometer sensors. Courtesy of Widhoc Smart Solutions.

Dados do potencial matricial do solo e volume de rega aplicado. A interface mostrada é usada para gestão da rega com MPS-6 e sensores pluviométricos. Cortesia da Widhoc Smart Solutions. 


\section{RESULTS AND DISCUSSION}

Irrigation management was carried out by using two different premises. During the first stage (DOY 135190), vines were irrigated with the same criteria in both plots, with the aim of studying the soil properties. From DOY 190 onward, the irrigation management was accomplished by using the information provided by the soil water potential sensors. In this case, the intended value for the soil was kept around $-30 \mathrm{kPa}$, sending irrigation commands when values under such threshold were reported. Figure 3 shows the data of the irrigation management by using the matric water potential sensors and the amount of water supplied. The interface belongs to Widhoc Smart Solutions (Fuente Alamo, MU - Spain).

In order to have more information, the water volume reported by the farmer (according to local practices), was also checked. This was useful for comparing the results obtained with the use of the sensors with those provided by the farmer. In addition, midday stem water potential and fluorescence measurements (fortnightly) were also collected with the purpose of better verifying the irrigation conditions. The midday stem water potential is very representative of the level of water deficit of the vine (Choné et al. 2001).

A threshold value of -0,6 MPa was defined in order to ensure the appropriate water potential for the vine, since values 0.5-0.8 MPa can be considered indicative of no or very little stress (Tramontini et al., 2013).

Figure 4 shows the evolution of the air vapour pressure in both treatments (tilled and mulched) during a period of time with high evaporative demand (DOY 209-221). Several differences were observed, mainly during the hours of highest evapotranspiration. In particular, the vapour pressure was higher in the living mulch plot, with values that exceeded $3 \mathrm{kPa}$, whereas the plot without mulching hardly reached such value. This fact did not involve a higher water consumption. Specifically, a value of $1296.52 \mathrm{~m}^{3} \mathrm{ha}^{-1}$ was the irrigation volume in the plot with mulching during a period of 60 days, since the irrigation management procedure started (coincident with the maximum transpiration demand, DOY 205265). On the other hand, during the same period, the volume irrigation in the ploughed soil reached $1448.66 \mathrm{~m}^{3} \mathrm{ha}^{-1}$. Although the difference between the two measurements was not significant (barely a $10 \%$ ), the expected results would be a higher volume of water in the plot with Trifolium repens.

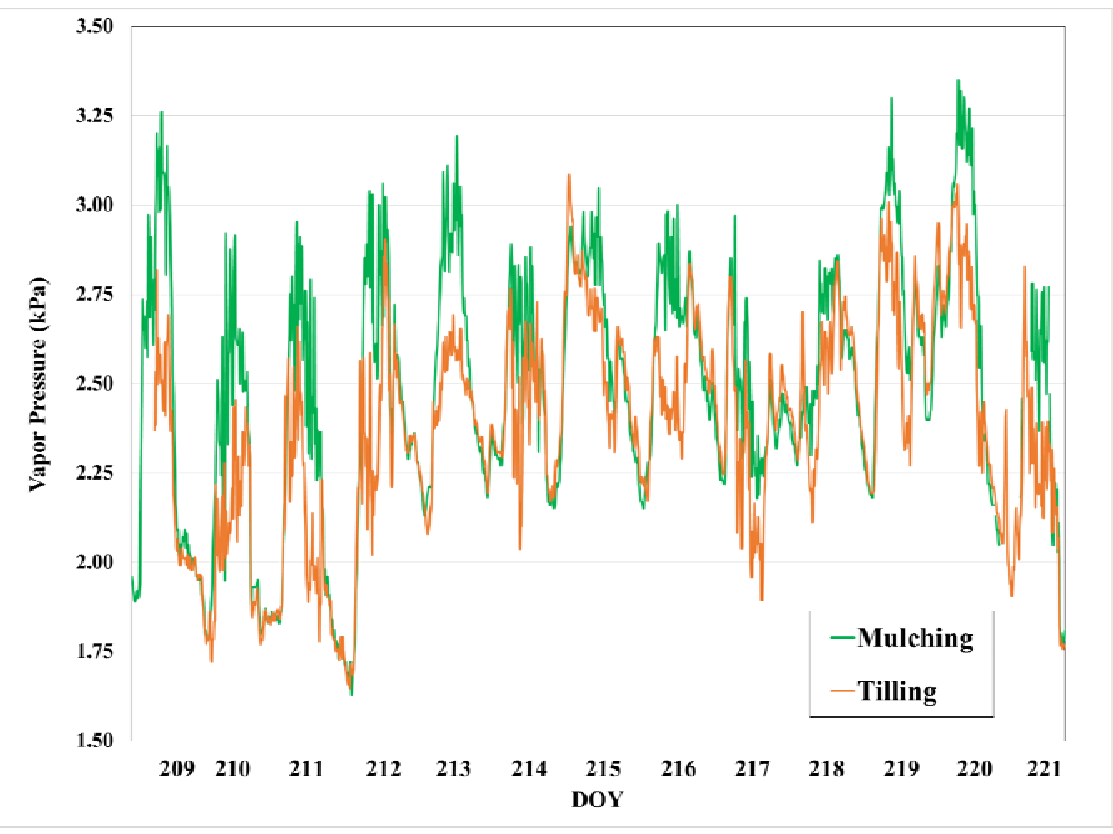

Figure 4. Air Vapor Pressure in the two plots, tilled and mulched.

Pressão de vapor do ar nas duas parcelas, mobilizada e com mulch. 
The data of the soil water content profiles were necessary to perform a temporal study of the soil water retention capacity in each soil. For this purpose, several humidity sensors located at different depths were used.

The variables were analysed using the same irrigation cycles, that is, in the same days and with the same duration (DOY 135-205). The measurements were taken between repetitions of each treatment. The analysis was carried out by using sensors at $25 \mathrm{~cm}$ and $50 \mathrm{~cm}$ for each repetition. During such period, 12 irrigation cycles were analysed. Figure 5 shows the evolution of the most representative volumetric soil water content sensor at $25 \mathrm{~cm}$ and $50 \mathrm{~cm}$ in both plots, after an irrigation episode in one of the two repetitions measured.

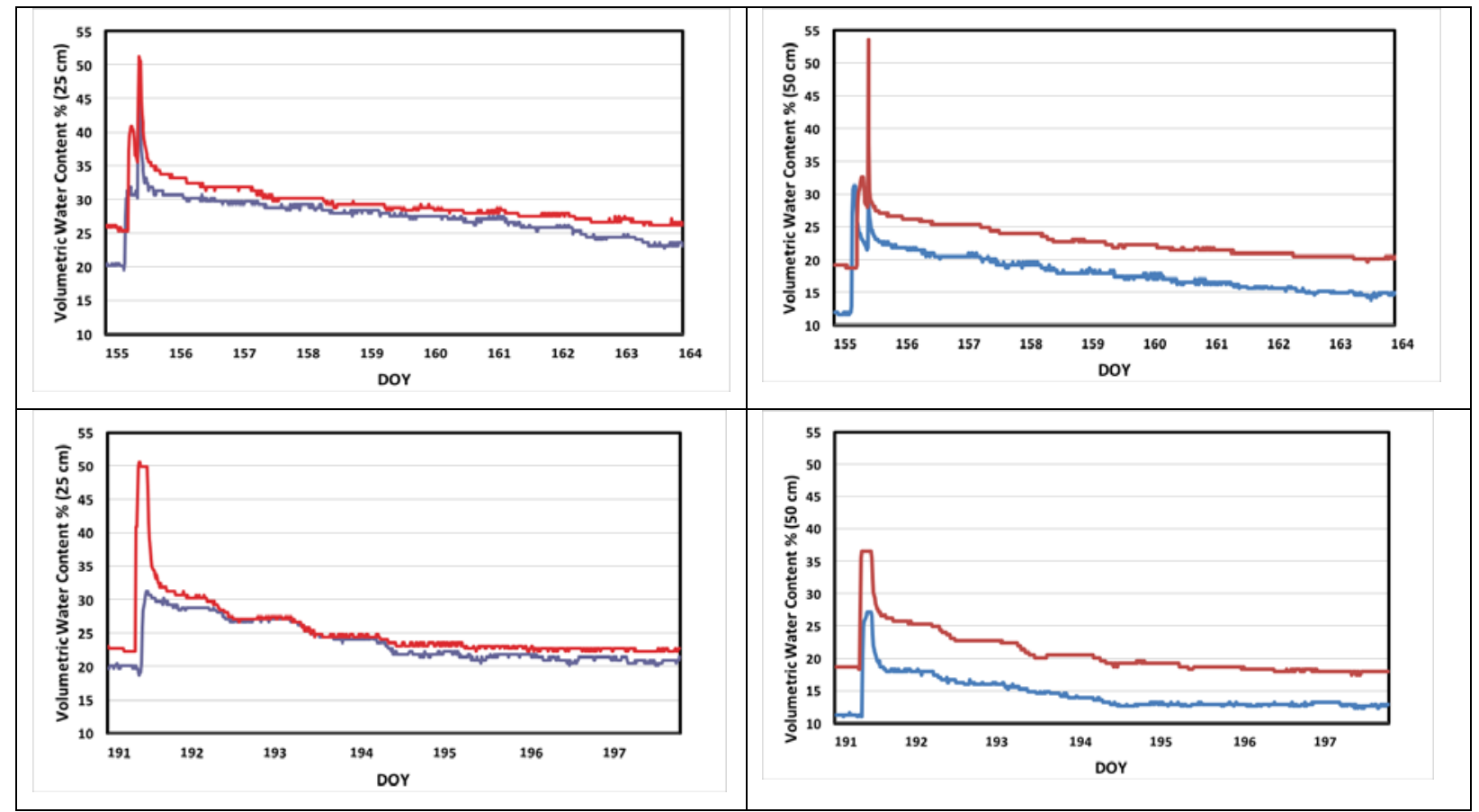

Figure 5. Evolution of the volumetric soil water content in both plots during two most representative irrigation episodes at $25 \mathrm{~cm}$ of depth (left) and $50 \mathrm{~cm}$ depth (right). Blue for Mulching plot and red for Tilling plot.

Evolução do teor volumétrico de água do solo em ambas as parcelas durante dois episódios de rega mais representativos a $25 \mathrm{~cm}$ de profundidade (esquerda) e $50 \mathrm{~cm}$ de profundidade (direita). Azul para a parcela com Mulch e vermelho para a parcela Mobilizada.

Results clearly showed the beginning of irrigation episodes in both plots.

Furthermore, after analysing these data, results also showed a very marked gradient in the tilled plot (redcoloured), immediately after irrigation. This effect can be observed at $25 \mathrm{~cm}$ clearly. In fact, a rapid decrease of the water content was observed, probably due to the limited soil retention capacity. However, it was slightly different at $50 \mathrm{~cm}$ depth, where this gradient after irrigation becomes similar. The time that the variable $\theta \mathrm{v}$ takes to reach the same value that has been measured before the irrigation episode is also shown in Figure 5 for two most representative irrigation episodes.

The problem of these representations is the offset of the lines $(\theta \mathrm{v}$ at the $\mathrm{Y}$ axis). Really, in order to perform the temporal study of the water in the soil, it is not necessary to know the absolute value of the $\theta \mathrm{v}$, but the gradient or evolution of the water content during the time. This gradient is the indicator of how much time the water is kept in the soil. At both soil depths, 25 and $50 \mathrm{~cm}$, the reduction of water content is clear and the faster reduction at $50 \mathrm{~cm}$ can be explained by the soil characteristics in the vineyard. In particular, this soil has been subjected to rock fragmentation and grinding, as usual procedure in table grape vineyards in Puglia (Ferrara et al., 2012b). At $50 \mathrm{~cm}$ there are more skeletal fractions of medium size, which cause a faster drainage of the water with respect of the $25 \mathrm{~cm}$ profile (Ferrara et al., 2012b).

In order to show this feature, two most representative graphical representations of the 12 irrigation 


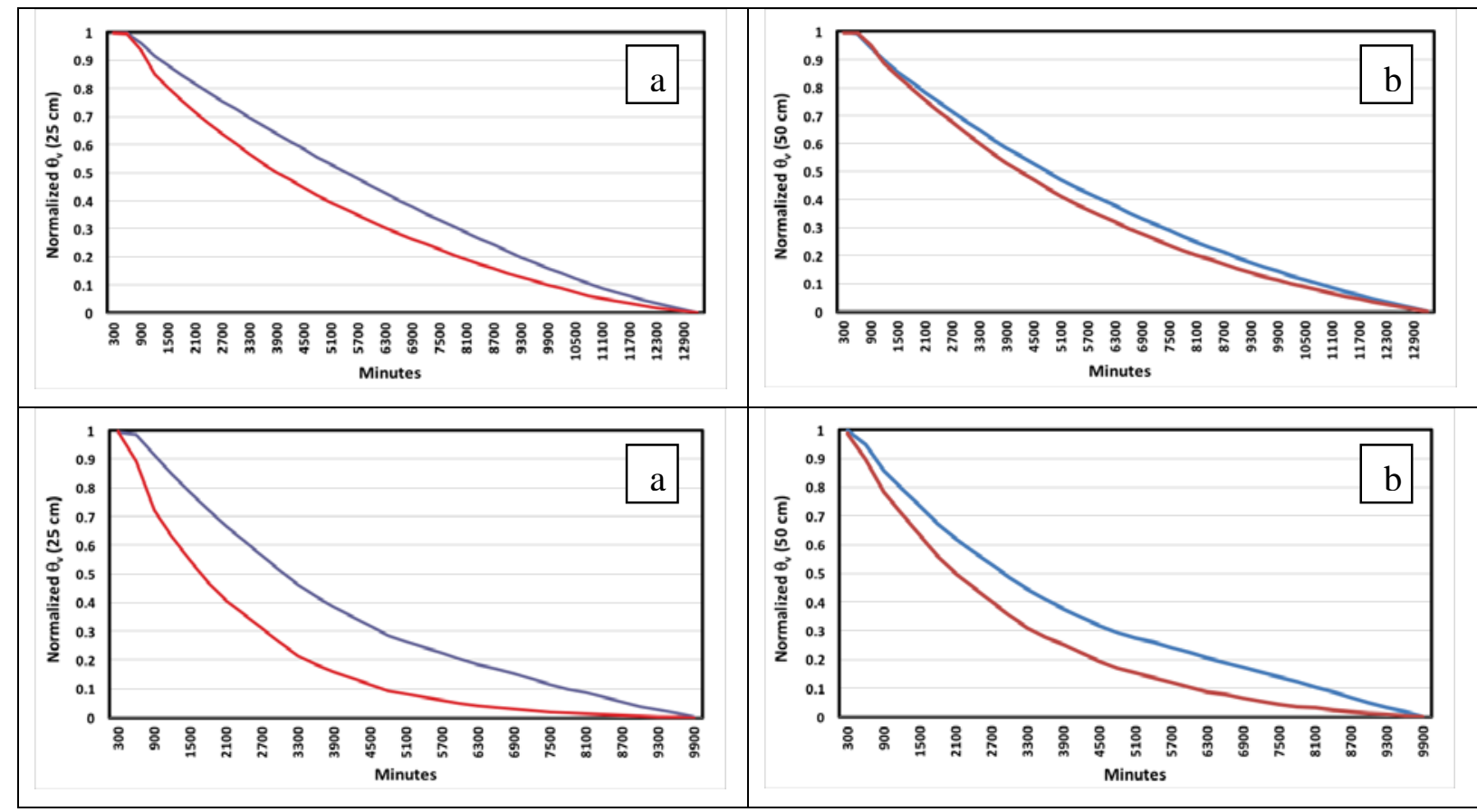

Figure 6. Normalized curves of soil water content values in the two irrigation episodes at $25 \mathrm{~cm}$ of depth (a) and at $50 \mathrm{~cm}$ depth (b). Blue for Mulching plot and red for Tilling plot.

Curvas normalizadas de valores de teor de água do solo nos dois episódios de rega $25 \mathrm{~cm}$ de profundidade (a) e a $50 \mathrm{~cm}$ de profundidade (b). Azul para a parcela com Mulch e vermelho para a parcela Mobilizada.

The minimum moisture value of each curve is taken, and subtracted from each curve (remove offsets). A cubic interpolation is performed to obtain a higher density of work points (especially interesting in the area of the rise). The factor parameter indicates the number of points to have for each of the original points.

The enclosed area is calculated under each of the curves (with the offsets removed). Both curves are normalized by dividing each of their values by the area.

These curves are already normalized and can be compared directly. Two types of parameters are taken to characterize the terrain.

The process to analyze and draw the curves of a more appropriate mode is as follows.

At the first, the offset values of the curves are removed:

$$
\begin{aligned}
& \text { offset }= \min (\text { curves }(:, 1)) ; \\
& \% \text { To get the offset of data lines } \\
& \text { for } i=1: n \quad \text { time }(i)=(i-1) * 15 ;
\end{aligned}
$$

\section{\%Time between sampling}

curves $(i, 1)=\operatorname{curves}(i, 1)$-offset1;

$\%$ Redraw lines with the same origin

A cubic interpolation is performed to obtain a higher density of points of work (especially interesting in the area of the climb). The factor parameter (has value 4 in this work) indicates the number of points to each of the original points.

$$
\begin{aligned}
& \text { npoints }=n * \text { factor; } \\
& \quad \% 4 \text { points per sample } \\
& \text { f(i)=interp1(time,curves(:,1),(i- } \\
& 1) * 15 / \text { factor,'cubic'); }
\end{aligned}
$$

The enclosed area under each of the curves (with offsets removed) is obtained.

$$
\begin{aligned}
& \text { deltatime }=\text { sampling } / \text { npoints; } \\
& \text { area }=\text { area }+f(i) * \text { deltatime; }
\end{aligned}
$$

Both curves are normalized by dividing each of its values in the area.

$$
f=f^{*}(1 / \text { area }) \text {; }
$$


After carrying out a numerical analysis of the normalized curves shown in Figure 6, the represented values have been integrated with the purpose of calculating the total volume per unit time.

$$
\begin{gathered}
\text { ncomp }=\text { floor(sampling/freccomp); } \\
\% \text { Round to next smaller integer } \\
\text { acumulated }(j, 1)=j^{*} \text { freccomp; } \\
\text { acum }=\text { acum }-f(i) * \text { deltatime; } \\
t 25 c 1=t(i) / 60 \\
\% \text { Time to } 25 \% \text { water loss in mulching } \\
\text { t50c1= } t(i) / 60 \\
\% \text { Time to } 50 \% \text { water loss in mulching }
\end{gathered}
$$

$$
\begin{aligned}
& t 75 c 1=t(i) / 60 \\
& \quad \% \text { Time to } 75 \% \text { water loss in mulching } \\
& \text { acumulated }(j, 2)=\text { acum; }
\end{aligned}
$$

Accumulated: Indicates how much water remains on the soil at any given time in both depths Figures $6 a$ and $6 \mathrm{~b}$ show two most representative episodes of irrigation.

Time parameters: Time in hours that the water volumetric content is present in a given proportion and at the concrete depth (25 and $50 \mathrm{~cm}$ ) with respect to the volume of water supplied in the

\begin{tabular}{|c|c|c|}
\hline \multicolumn{3}{|c|}{ Irrigation 6 (DOY 155) } \\
\hline $25 \%$ & $45.81-39,56 \mathrm{~h}$ & $30.75-35.56 \mathrm{~h}$ \\
\hline $50 \%$ & $90.50-80 \mathrm{~h}$ & $65.19-70.06 \mathrm{~h}$ \\
\hline $75 \%$ & 143.19-134.63 h & $118.81-121.875 \mathrm{~h}$ \\
\hline \multicolumn{3}{|c|}{ Irrigation 8 (DOY 173) } \\
\hline $25 \%$ & 25.37-20.,44 h & $16.06-17.81 \mathrm{~h}$ \\
\hline $50 \%$ & $44.56-37.19 \mathrm{~h}$ & 31.87-33.81 h \\
\hline $75 \%$ & $68.62-61.06 \mathrm{~h}$ & $57.37-58,87 \mathrm{~h}$ \\
\hline \multicolumn{3}{|c|}{ Irrigation 10 (DOY 184) } \\
\hline $25 \%$ & $33.00-26.87 \mathrm{~h}$ & $21.50-26.56 \mathrm{~h}$ \\
\hline $50 \%$ & 61.12-53.31 h & $47.50-51.68 \mathrm{~h}$ \\
\hline $75 \%$ & $94.81-85.25 \mathrm{~h}$ & $82.50-88.5 \mathrm{~h}$ \\
\hline \multicolumn{3}{|c|}{ Irrigation 12 (DOY 198) } \\
\hline $25 \%$ & 44.31-34.62 h & $30.81-33.68 \mathrm{~h}$ \\
\hline $50 \%$ & 85.69-73.56 h & 69.69-72.18 h \\
\hline $75 \%$ & 134.12-123.75 h & 119.62-121.87 h \\
\hline Water loss & Living Mulch & Tilling \\
\hline
\end{tabular}
irrigation episode and measured as the area of the normalized curve (25\%, 50\% y 75\%). (TABLE II)

\section{TABLE II}

Information about the total volume per unit time calculated in each irrigation episode. Informação sobre o volume total por unidade de tempo calculado em cada episódio de rega.

\begin{tabular}{ccc}
\hline Water loss & L. Mulch (25-50) & Tilling (25-50) \\
\hline \multicolumn{3}{c}{ Irrigation 1 (DOY 135) } \\
\hline $25 \%$ & $21.62-19.2 \mathrm{~h}$ & $12.63-16.06 \mathrm{~h}$ \\
$50 \%$ & $42.44-33.69 \mathrm{~h}$ & $38.25-34.94 \mathrm{~h}$ \\
$75 \%$ & $67.75-55.19 \mathrm{~h}$ & $76.00-60.12 \mathrm{~h}$
\end{tabular}

\begin{tabular}{ccc}
\hline Water loss & L. Mulch (25-50) & Tilling (25-50) \\
\hline \multicolumn{3}{c}{ Irrigation 2 (DOY 140) } \\
\hline $25 \%$ & $17.62-15.31 \mathrm{~h}$ & $18.87-20.19 \mathrm{~h}$ \\
$50 \%$ & $29.68-25.81 \mathrm{~h}$ & $30.00-31.56 \mathrm{~h}$ \\
$75 \%$ & $44.69-38.75 \mathrm{~h}$ & $45.19-46.5 \mathrm{~h}$
\end{tabular}

\begin{tabular}{ccc}
\multicolumn{3}{c}{ Irrigation 3 (DOY 143) } \\
\hline $25 \%$ & $18.06-16.12 \mathrm{~h}$ & $16.50-16.5 \mathrm{~h}$ \\
$50 \%$ & $32.19-28, .7 \mathrm{~h}$ & $31.00-29.37 \mathrm{~h}$ \\
$75 \%$ & $52.31-45.06 \mathrm{~h}$ & $50.75-48 \mathrm{~h}$
\end{tabular}

\begin{tabular}{ccc}
\multicolumn{3}{c}{ Irrigation 4 (DOY 147) } \\
\hline $25 \%$ & $18.69-16.31 \mathrm{~h}$ & $11.5-12,56 \mathrm{~h}$ \\
$50 \%$ & $30.44-26,62 \mathrm{~h}$ & $25.44-25,87 \mathrm{~h}$ \\
$75 \%$ & $48.06-39.62 \mathrm{~h}$ & $44.87-44,87 \mathrm{~h}$
\end{tabular}

\begin{tabular}{crc}
\multicolumn{3}{c}{ Irrigation 5 (DOY 151) } \\
\hline $25 \%$ & $19.75-16.06 \mathrm{~h}$ & $15.87-17,94 \mathrm{~h}$ \\
$50 \%$ & $32.25-27.81 \mathrm{~h}$ & $28.37-30.12 \mathrm{~h}$ \\
$75 \%$ & $49.69-42.69 \mathrm{~h}$ & $45.62-47.75 \mathrm{~h}$
\end{tabular}


According to the information shown in table 2, an averaged analysis of the 12 irrigation cycles was performed, comparing the differences between the times of both treatments.

The results reflect that, for $25 \mathrm{~cm}$ depth sensors, the average times in hours for a reduction of the volumetric content of $25 \%, 50 \%$ and $75 \%$ were:

$\begin{array}{lll}\text { 25\% reduction } & 27,52 \mathrm{~h}(\mathrm{mul}) & 19,09 \mathrm{~h}(\text { till) } \\ 50 \% \text { reduction } & 50,82 \mathrm{~h}(\mathrm{mul}) & 40,22 \mathrm{~h}(\text { till) } \\ 75 \% \text { reduction } & 80,63 \mathrm{~h}(\mathrm{mul}) & 71,13 \mathrm{~h}(\text { till) }\end{array}$

By performing a percentage analysis, the sensors reflect that, at $25 \mathrm{~cm}$ depth, the average time it takes the volumetric content to reach the initial value before irrigation, is $21 \%$ higher in the mulching treatment than in the tilling one.

Regarding the analysis at $50 \mathrm{~cm}$ depth, the results show the following data:

\section{CONCLUSIONS}

Using living mulch in table grapes crops under a plastic sheet cover could be considered as a beneficial technique in terms of soil water retention capacity, increase of organic matter content and reduction of inputs. Under the study conditions, the possible competition of the living mulch for water has not been quantified, with the exception of the results obtained after managing the irrigation by considering the water potential. However, collected water consumption data during the season showed a slight difference in favour of the living mulch plot (less consumption). Although the differences observed in the volumetric content of water in the soil at $25 \mathrm{~cm}$ have been quite determinant, this has not been the case for the values measured at $50 \mathrm{~cm}$. However, our results indicated that the use of living mulch has not affected the conditions of soil moisture and, in addition, a reduction in water consumption has been achieved. Climatic sensors have shown a higher vapour pressure with living mulch consequence of a greater transpiration due to

\section{REFERENCES}

Carter A.D., Hollis J.M., Thompson T.R.E., Oakes D.B., Binney R., 1991. Pesticide contamination of water sources: current policies for protection and a multidisciplinary proposal to aid future planning, in: Brighton Crop Prot. Conf. Weeds. pp. 491-498.

Choné X., van Leeuwen C., Dubourdieu D., Gaudillère J.-P., 2001. Stem water potential is a sensitive indicator for grapevine water status. Ann Bot., 87, 477-483

$\begin{array}{lll}25 \% \text { reduction } & 22,71 \mathrm{~h}(\mathrm{mul}) & 21,24 \mathrm{~h}(\mathrm{till}) \\ 50 \% \text { reduction } & 43,46 \mathrm{~h}(\mathrm{mul}) & 41,62 \mathrm{~h}(\mathrm{till}) \\ 75 \% \text { reduction } & 72,14 \mathrm{~h}(\mathrm{mul}) & 71,56 \mathrm{~h}(\mathrm{till})\end{array}$

With the same previous percentage analysis, at $50 \mathrm{~cm}$ depth the average time it takes the volumetric content to reach the initial value before the irrigation in the mulching treatment is $3.8 \%$ higher than the tilling one.

According to the measurements made in this test, the results obtained show that in the Living Mulch plot:

- Irrigation volume applied was lower.

- Volumetric water content stays longer at certain values (very decisive at $25 \mathrm{~cm}$, practically equal to 50 $\mathrm{cm})$.

- The vapour pressure measured have been slightly superior in the plot with living mulch.

the presence of Trifolium repens. Although such differences were not essential or significant and two repetitions are not representative of the soil dispersion, this study shows that the use of living mulch could be a beneficial agricultural technique due to environmental reasons and it would support the increase of organic food demand by consumers. The use of WSNs and Cloud Computing technologies, with WEB services through the PC or APP platforms, have been shown as flexible and very effective tools to control the irrigation procedure and to efficiently use the crop inputs.

\section{ACKNOWLEDGEMENTS}

The development of this work was supported by: The Spanish Ministry of Science and Innovation through the project RIDEFRUT (ref. AGL2013-49047-C2-1$\mathrm{R})$, the "Fundacion Seneca, Agencia de Ciencia y Tecnologia" of the Region of Murcia under the "Excelence Group Program", and the Technical University of Cartagena under the PMPDI Program.

Cousens R., Mortimer M., 1995. Dynamics of weed populations, Cambridge University Press. doi:10.1007/978-90-481-9277-9

Ferrara G., Farrag K., Brunetti G., 2012b. The effects of rock fragmentation and/or deep tillage on soil skeletal material and chemical properties in a Mediterranean climate. Soil Use Manag., 28, 394-400.

Ferrara G., Fracchiolla M., Al Chami Z., Camposeo S., Lasorella C., Pacifico A., Aly A., Montemurro P., 2012a. Effects of mulching materials on soil and performance of cv. Nero di Troia grapevines in the Puglia Region, Southeastern Italy. Am. J. Enol. Vitic., 63, 269-276. 
Ferrara G., Mazzeo A., Matarrese A.M.S., Pacifico A., Fracchiolla M., Al Chami Z., Lasorella C., Montemurro P., Mondelli D., 2015. Soil management systems: effects on soil properties and weed flora. S. Afr. J. Enol. Vitic., 36, 11-20.

Hall J.K., N.L Hartwig, L.D. Hoffman, 1984. Cyanazine losses in runoff from no-tillage corn in "living" and dead mulches vs. unmulched, conventional tillage. J. Environ. Qual., 13, 105-110.

Hartwig N.L., Ammon H.U., 2002. Cover Crops and Living Mulches. Weed Sci., 50, 688-699.

Haynes R.J., 1980. Influence of soil management practice on the orchard agro-ecosystem. Agro-Ecosystems, 6, 3-32.

López J.A., Navarro H., Soto F., Pavón N., Suardíaz J., Torres R., 2015. GAIA2: A multifunctional wireless device for enhancing crop management. Agric. Water Manag., 151, 75-86.

Major C.S., 1992. Addressing public fears over pesticides. Weed Technol., 6, 471-472.

Merwin I.A., Rosenberger D.A., Engle C.A., Rist D.L., Fargione M., 1995. Comparing mulches, herbicides, and cultivation as orchard groundcover management systems. Horttechnology, 5, 151-158.
Morais R., Fernandes M.A., Matos S.G., Serôdio C., Ferreira P.J.S.G., Reis M.J.C.S., 2008. A ZigBee multi-powered wireless acquisition device for remote sensing applications in precision viticulture. Comput. Electron. Agric., 62, 94-106.

Navarro-Hellín H., Torres-Sánchez R., Soto-Valles F., AlbaladejoPérez C., López-Riquelme J.A., Domingo-Miguel R., 2015. A wireless sensors architecture for efficient irrigation water management. Agric. Water Manag., 151, 64-74.

Tramontini S., van Leeuwen C., Domec J.C., Destrac-Irvine A., Basteau C., Vitali M., Mosbach-Schulz O., Lovisolo C., 2013. Impact of soil texture and water availability on the hydraulic control of plant and grape-berry development. Plant Soil, 368, 215230.

Verdú A.M., Mas M.T., 2007. Mulching as an alternative technique for weed management in mandarin orchard tree rows. Agron. Sustain. Dev., 27, 367-375.

Welker W.V., D.M. Glenn, 1988. Growth responses of young peach trees and changes in soil characteristics with sod and conventional planting systems. J. Amer. Soc. Hort. Sci., 113, 652656. 